\title{
FORMULASI SEDIAAN KRIM A/M DENGAN VARIASI KONSENTRASI EKSTRAK ETANOL DAGING BUAH PEPAYA (Carica Papaya) MENGGUNAKAN EMULGATOR TWEEN 80 DAN SPAN 80
}

Formulation Of A/M Cream With The Concentration Variation Of Ethanol Of Papaya Extract (Carica Papaya) Using Tween 80 And Span 80 Emulgators

\author{
Gita Puspita ${ }^{1}$, Nining Sugihartini2* ${ }^{*}$, Iis Wahyuningsih ${ }^{2}$ \\ ${ }^{1}$ Universitas Bina Mandiri, Gorontalo \\ ${ }^{2}$ Universitas Ahmad Dahlan, Yogyakarta
}

*Koresponden Email : nining.sugihartini@pharm.uad.ac.id

DOI: https://doi.org/10.32382/mf.v16i1.1421

\begin{abstract}
Papaya (Carica papaya) contains flavonoid and phenolic compounds proven to have sunscreen and antithyrosinase activity. For this reason, there is a need to formulate them in the form of cream preparations. This study analyzes the effect of the ethanol extract concentration of papaya flesh in the form of A / $M$ cream preparations on their physical properties. The extracts were obtained using the maceration method with $70 \%$ ethanol solvent in A / M cream preparations and concentrations of 1\%, 3\%, and 5\% through Tween 80 and Span 80 emulgators. Creams were evaluated for physical properties, including $\mathrm{pH}$, adhesion, dispersion, viscosity, and physical stability. The test results showed that an increase in the concentration of ethanol extract led to a decrease in $\mathrm{pH}(p<0.05)$, viscosity $(p<0.05)$, adhesion ( $p<0.05)$, and an increase in dispersion ( $p<0.05)$. Additionally, phase separation occurs at a concentration of $5 \%$ papaya fruit extract cream. These results show that variations in the ethanol extract concentration of papaya fruit influence the physical properties of A / $M$ cream.
\end{abstract}

Keywords: Carica papaya; A / M cream; Physical Properties.

\section{ABSTRAK}

Pepaya (Carica papaya) mengandung senyawa flavonoid dan fenolik yang terbukti memiliki aktivitas sebagai tabir surya dan antitirosinase sehingga perlu diformulasikan dalam bentuk sediaan krim. Tujuan dari penelitian ini adalah untuk mengetahui pengaruh konsentrasi ekstrak etanol daging buah papaya dalam bentuk sediaan krim A/M terhadap sifat fisik sediaan. Ekstraksi buah papaya diperoleh dengan metode maserasi dengan pelarut etanol $70 \%$ dalam sediaan krim A/M dengan konsentrasi $1 \%$ (FI), 3\% (F2) Dan 5\% (F3). Krim dievaluasi sifat fisik meliputi pH, daya lekat, dan daya sebar, viskositas dan stabilitas fisik. Hasil uji menunjukkan bahwa peningkatan konsentrasi ekstrak etanol buah papaya menyebabkan penurunan $\mathrm{pH}(\mathrm{p}<0.05)$, viskositas $(\mathrm{p}<0.05)$, daya lekat $(\mathrm{p}<0.05)$, peningkatan daya sebar $(\mathrm{p}<0.05)$. Terjadi pemisahan fase pada konsentrasi $5 \%$ krim ekstrak buah papaya. Berdasarkan hasil dapat disimpulkan bahwa variasi konsentrasi ekstrak etanol daging buah papaya memiliki pengaruh terhadap sifat fisik krim A/M

Kata kunci : Carica papaya; krim A/M; Sifat Fisik.

\section{PENDAHULUAN}

Krim tipe A/M adalah bentuk emulsi yang memiliki perbandingan fase minyak lebih tinggi. Alasan pemilihan krim A/M pada penelitian ini karena memiliki penyebaran yang lebih baik dan daya lekat yang lebih lama, meskipun sedikit berminyak tetapi penguapan airnya berjalan lambat sehingga dapat mengurangi rasa panas dikulit (Dewi et al, 2010).

Konsentrasi zat aktif dalam sediaan akan menentukan efektivitas sediaan tersebut. alasan penentuan konsentrasi 1\%, 3\% dan 5\% yaitu berdasarkan penelitian sebelumnya pada konsentrasi rendah ekstrak kental daging buah pepaya sudah dapat melindungi kulit dari sinar ultraviolet (Khomaria, 2018).

Penggunaan jenis dan konstentrasi bahan tambahan maupun ekstrak yang berbeda akan mempengaruhi kestabilan fisik suatu sediaan sehingga uji stabilitas fisik terhadap formula optimum perlu dilakukan terhadap krim ekstrak etanol daging buah pepaya. Uji stabilitas fisik dilakukan untuk menjamin sediaan memiliki sifat sama setelah sediaan dibuat dan masih memenuhi parameter kriteria selama penyimpanan. Ketidakstabilan fisik dari sediaan krim ditandai dengan adanya pemucatan warna 
atau munculnya warna, timbul bau, perubahan atau pemisahan fase, perubahan konsistensi, terbentuknya gas dan perubahan fisik lainnya (Sayuti, 2015).

Kestabilan suatu zat merupakan suatu yang harus diperhatikan dalam membuat suatu sediaan farmasi. Hal ini penting karena suatu sediaan biasanya diproduksi dalam jumlah yang besar dan memrlukna waktu yang cukup panjang untuk sampai ke tangan konsumen. Oleh karena itu sediaan tersebut juga perlu diuji kestabilannya sesuai prosedur yang telah ditentukan. Sediaan krim yang stabil yaitu sediaan yang msih berada dalam batas yang dapat diterima selama masa periode penyimpanan dan penggunaan. Adanya zat aktif diperkirakan mempengaruhi kestabilan fisik dari setiap forrmula krim yang dibuat (Dewi et $a l, 2014)$. Pada penelitian ini akan duilakukan uji stabilitas fisik krim yang mengandung ekstak etanol daging buah pepaya.

Tujuan penelitian ini yaitu untuk mengetahui pengaruh variasi konsentrasi ekstrak etanol daging buah pepaya dalam basis krim A/M terhadap sifat fisik sediaan.

\section{METODE}

\section{Desain, tempat dan waktu}

Jenis penelitian ini merupakan penelitian eksperimental. Penelitian ini dilakukan di Laboratorium Universitas Ahmad Dahlan Yogyakartapada bulan Mei - November 2019.

\section{Alat dan Bahan}

Alat yang akan digunakan dalam penelitian ini antara lain timbangan analitik (Ohaus), sentrifugator (Gemmy PLC_03), oven, pH meter (Ohaus), penangas air (Memmert), viscometer (Rheosis)

Bahan yang digunakan dalam penelitian ini antara lain daging buah papaya California (Perkebunan Pepaya Pundong, Yogyakarta) umur 3-4 bulan, etanol 70\% (Merck). Bahan penyusun sediaan krim A/M dengan derajat farmasetis (BHT, cera alba, cetyl alcohol, Lanolin, propil paraben, metil paraben, Parafin liquidum, Span 80, Steril alcohol, Tween 80).

\section{Langkah-langkah Penelitian}

Penyiapan simplisia

Simplisia papaya dikeringkan selama lebih kurang 3 hari, terlindungi dari sinar matahari langsung, kemudian digiling untuk mendapatkan serbuk simplisia.

Pembuatan ekstrak

Serbuk buah papaya diekstraksi dengan metode maserasi menggunakan serbuk daging buah pepaya yang direndam dalam pelarut etanol $70 \%$, dengan rasio 1:4. Maserat yang telah diperoleh lalu diuapkan pelarutnya menggunakan rotary evaporator pada suhu 60$70^{\circ} \mathrm{C}$, dilanjutkan penguapan diatas water bath pada suhu $60-70^{\circ} \mathrm{C}$ hingga diperoleh ekstrak kental. Ekstrak kemudian disimpan dalam lemari pendingin sebelum digunakan dalam proses formulasi(Rokhmawatiet al, 2014).

Pembuatan krim.

Fase minyak dibuat dengan melebur berturut-turut paraffin liquidum, cetyl alcohol, lanolin, BHT, cera alba, dan span 80 di atas penangas air dengan suhu $80^{\circ} \mathrm{C}$, kemudian ditambahkan propil paraben, kemudian fase air dibuat dengan cara melarutkan metil paraben dan tween 80 dalam air yang telah dipanaskan. Emulsi dibuat dengan cara menambahkan fase minyak ke dalam fase air sambil diaduk dalam lumpang hingga terbentuk corpus emulsi yang stabil, kemudian ditambahkan sedikit demi sedikit ekstrak papaya gerus dalam lumpang hingga terbentuk emulsi yang homogen. Krim dimasukkan dalam wadah tertutup rapat dan diberi etiket (Suryatiet al, 2015). Formula sediaan krim A/M ekstrak daging buah pepaya dapat dilihat pada Tabel I.

Tabel I Formulasi krim air dalam minyak dengan konsentrasi ekstrak daging buah pepaya.

\begin{tabular}{ccccc}
\hline Bahan & $\begin{array}{c}\text { Fo } \\
\text { \%) }\end{array}$ & $\begin{array}{c}\text { F I } \\
\text { \%) }\end{array}$ & $\begin{array}{c}\text { F II } \\
(\%)\end{array}$ & $\begin{array}{l}\text { F III } \\
(\%)\end{array}$ \\
\hline Ekstrak etanol & & & & \\
Daging buah & 0 & 1 & 3 & 5 \\
pepaya & & & & \\
Parfin liquidum & 40 & 40 & 40 & 40 \\
Cetyl alkohol & 8 & 8 & 8 & 8 \\
Lanolin & 1,5 & 1,5 & 1,5 & 1,5 \\
Butyl hydroxyl & 0,1 & 0,1 & 0,1 & 0,1 \\
toluena & 2 & 2 & 2 & 2 \\
Cera alba & 6,7 & 6,7 & 6,7 & 6,7 \\
Span 80 & 1,3 & 1,3 & 1,3 & 1,3 \\
Tween 80 & 0,1 & 0,1 & 0,1 & 0,1 \\
Nipagin & 0,05 & 0,05 & 0,05 & 0,05 \\
Nipasol & Qs & Qs & Qs & Qs \\
Parfum & 100 & 100 & 100 & 100 \\
Aquadest ad & 100
\end{tabular}

Ket: F0: tidak memiliki ekstrak daging buah pepaya, F1 : Konsentrasi 1\% ekstrak daging buah pepaya, FII : Konsentrasi 3\% ekstrak daging buah pepaya, FIII : Konsentrasi 5\% ekstrak daging buah pepaya.

1. $\mathrm{Uji} \mathrm{pH}$

Sediaan krim diuji dengan menggunakan $\mathrm{pH}$ meter dicelupkan dalam sampel. Nilai $\mathrm{pH}$ 
yang ditunjukan dicatat dan direplikasi sebanyak 3 kali (Ali et al, 2019).

2. Uji Viskositas

Sediaan ditentukan viskositasnya dengan viskosimeter Rheosys Merlin VR dengan menggunakan spindel $25 \mathrm{~mm}$ concentriccylinders. Krim ditempatkan ke dalam plate dan cone. Parameter pengukuran diatur agar samapersis sehingga semua formula mendapatkan perlakuan yang sama kemudian dijalankan komputer dengan aplikasi Rheosys Micra(Edityanigrum, 2018).

3. Uji Daya Sebar

Sebanyak $500 \mathrm{mg}$ krim diletakkan diatas kaca bulat yang berdiameter $15 \mathrm{~cm}$, kemudian ditutup dengan menggunakan kaca bulat yang telah ditimbang dan diketahui bobotnya selam 5 menit serta dicatat diameter penyebarannya. Beban seberat 50 g diletakkan diatasnya dan didiamkan selama 1 menit, kemudian dilanjutkan dengan penambahan beban 100, 150, dan $200 \mathrm{~g}$ dicatat dan dihitung diameter penyebarannya. Replikasi dilakukan sebanyak 3 kali(Dewi et al, 2010).

4. Uji Daya Lekat

Sebanyak 500mg krim diletakkan di atas gelas objek yang telah ditentukan luasnya. Gelas obyek yang lain diletakkan di atas krim tersebut. Setelah itu beban $1 \mathrm{~kg}$ ditambahkan selama 5 menit pada gelas obyek dan dipasang pada alat tes. Berat beban 80 gram dilepaskan, dicatat waktunya hingga kedua gelas obyek tersebut terlepas. Percobaan diulangi sebanyak $3 \mathrm{kali}$. Uji daya lekat krim dilakukan untuk mengetahui kemampuan krim melekat pada tempat aplikasinya (Haque \& Sugihartini, 2005).

5. Uji Stabilitas

Pengujian Stabilitas fisik dilakukan dengan sentrifugasi, sebanyak $10 \mathrm{~g}$ sampel krim ditempatkan dalam tabung sentrifugasi (diameter $1 \mathrm{~cm}$ ) dan disentrrifugasi $3750 \mathrm{rpm}$ selama 5 jam atau 5000-10000 rpm selama 30 menit, kemudian terjadi pemisahan fase (Rieger, 2000).

Pengumpulan dan Analisis Data

Data yang diperoleh berupa data hasil evaluasi sifat fisik sediaan krim yang meliputi nilai $\mathrm{pH}$, viskositas, daya sebar, saya lekat dan stabilitas krim. Data yang diperoleh diuji statistik dengan menggunakanStatistical Product and Services Solution (SPSS).

HASIL

Hasil penelitian dapat dilihat dibawah ini

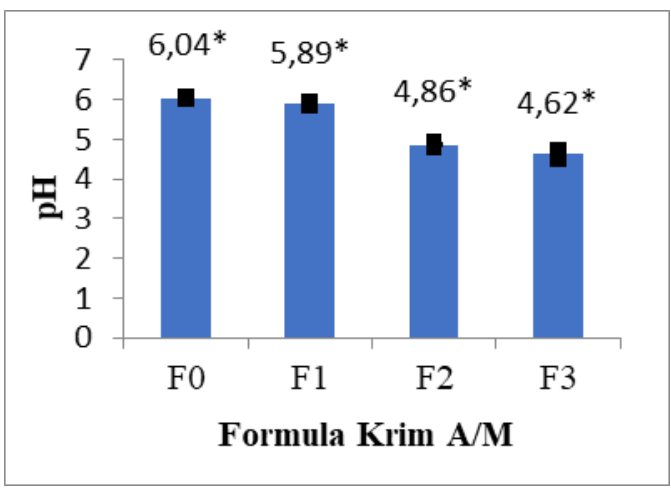

Gambar 1 .Grafik Hasi Uji pH Krim A/M dengan Variasi Konsentrasi ekstrak.

Ket : F0: tidak memiliki ekstrak daging buah pepaya, F1: Konsentrasi 1\% ekstrak daging buah pepaya, FII: Konsentrasi 3\% ekstrak daging buah pepaya, FIII: Konsentrasi 5\% ekstrak daging buah pepaya, *: ada perbedaan antar kelompok

Hasil menunjukkan pada pengujian $\mathrm{pH}$ terjadi perbedaan yang signifikan. antara basis, krim ekstrak 1\% (F1), krim ekstrak 3\% (F2) dan krim ekstrak 5\% (F3).

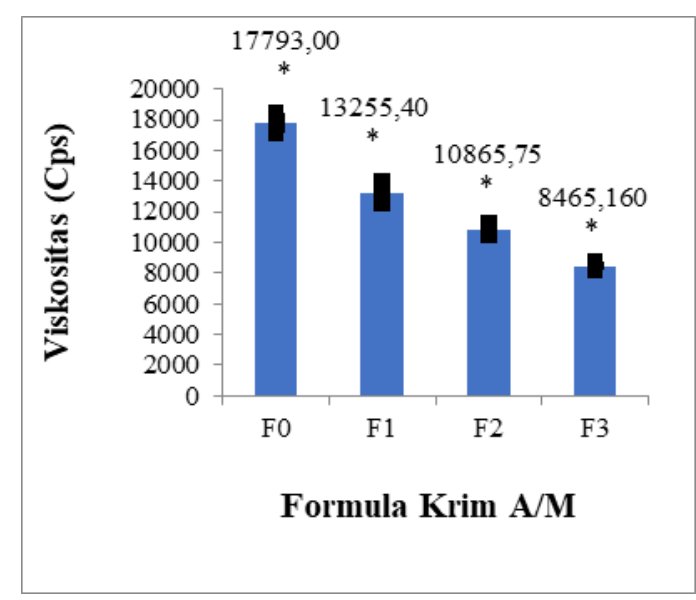

Gambar 2. Grafik Hasil Penetapan Viskositas Krim A/M dengan Variasi Konsentrasi EkstrakDaging Buah Pepaya

Ket : F0: tidak memiliki ekstrak daging buah pepaya, F1: Konsentrasi 1\% ekstrak daging buah pepaya, FII: Konsentrasi 3\% ekstrak daging buah pepaya, FIII: Konsentrasi 5\% ekstrak daging buah pepaya, *: ada perbedaan antar kelompok

Hasil menunjukkan bahwa terjadi perbedaan yang signifikan pada pengujian viskositas antara basis, krim ekstrak 1\% (F1), 
krim estrak 3\% (F2) dan krim ekstrak 5\% (F3).

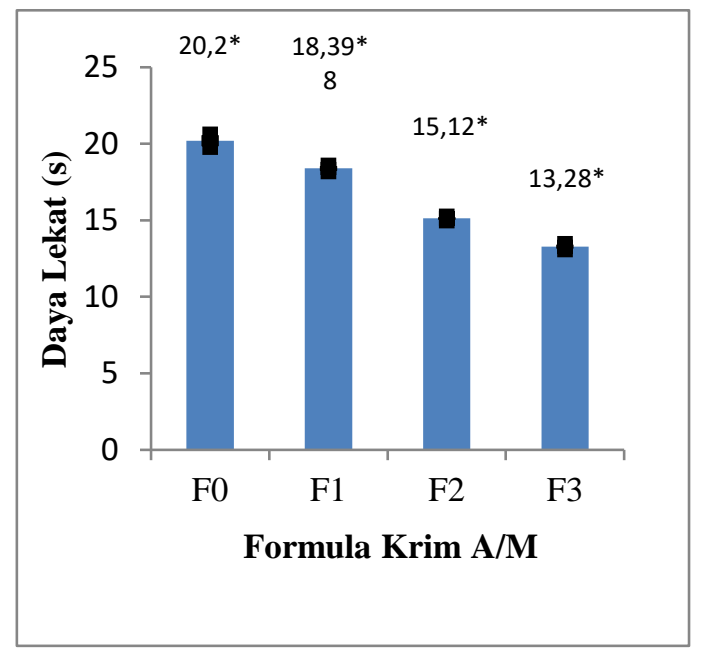

Gambar 3. Grafik Hasil Uji Daya Lekat Krim A/M dengan Variasi Konsentrasi Ekstrak Daging Buah Pepaya

Ket : F0: tidak memiliki ekstrak daging buah pepaya, F1: Konsentrasi $1 \%$ ekstrak daging buah pepaya, FII: Konsentrasi 3\% ekstrak daging buah pepaya, FIII: Konsentrasi 5\% ekstrak daging buah pepaya, *: ada perbedaan antar kelompok

Hasil menunjukkan bahwa terjadi perbedaan yang signifikan pada pengujian daya lekat antara basis, krim ekstrak 1\% (F1), krim estrak 3\% (F2) dan krim ekstrak 5\% (F3).

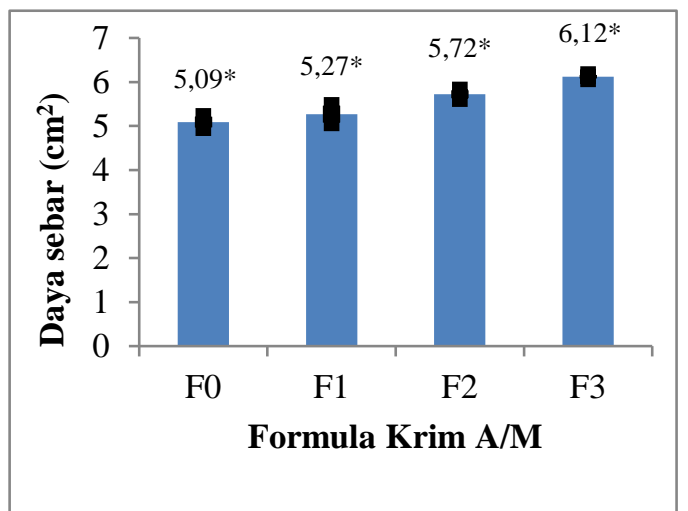

\section{Gambar 4.Grafik Hasil Uji Daya Sebar Krim A/M dengan Variasi Konsentrasi Ekstrak Daging Buah Pepaya,} Ket : F0: tidak memiliki ekstrak daging buah pepaya, F1: Konsentrasi 1\% ekstrak daging buah pepaya, FII: Konsentrasi 3\% ekstrak daging buah pepaya, FIII: Konsentrasi 5\% ekstrak daging buah pepaya, *: ada perbedaan antar kelompok

Hasil menunjukkan bahwa terjadi perbedaan yang signifikan pada pengujian daya sebar antara basis, krim ekstrak 1\% (F1), krim estrak 3\% (F2) dan krim ekstrak 5\% (F3).

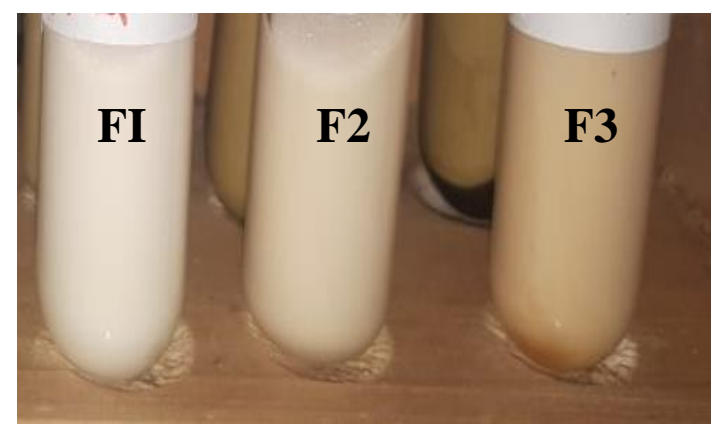

Gambar 5. Hasil Uji Sentrifugasi Krim A/MEkstrak Buah Papaya Dengan Menggunakan Variasi Konsentrasi Ekstrak Daging Buah Pepaya.

Ket : F0: tidak memiliki ekstrak daging buah pepaya, F1: Konsentrasi $1 \%$ ekstrak daging buah pepaya, FII: Konsentrasi 3\% ekstrak daging buah pepaya, FIII: Konsentrasi $5 \%$ ekstrak daging buah pepaya, *: ada perbedaan antar kelompok

Hasil menunjukkan terdapat pemisahan fase pada FIII : konsentrasi 3\% ekstrak daging buah pepaya.

\section{PEMBAHASAN}

Bahan yang digunakan pada penelitian ini adalah buah papaya California mengkal dengan usia buah 3-4 bulan yang diperoleh dari kebun buah papaya California Agro buah Pundong, Yogyakarta. Alasan pengambilan buah papaya mengkal karena mengacu pada penelitian Maisarahet al (2013) buah papaya belum matang memiliki aktivitas antioksidan lebih besar dibandingkan yang sudah matang. Penarikan jumlah senyawa aktif yang terkandung dipengaruhi oleh jenis pelarut yang dipilih, sesuai konsep like dissolve like, dimana senyawa yang bersifat polar akan larut dalam pelarut polar dan senyawa yang bersifat non polar akan larut dalam pelarut yang non polar (Arifianti et al, 2014). Pemilihan etanol $70 \%$ karena mengacu pada penelitian Khomaria (2018).yaitu pelarut yang memberikan hasil kandungan total flavonoid tertinggi terdapat pada ekstrak buah papaya dengan pelarut etanol $70 \%$ dibandingkan dengan etanol 50\% maupun etanol $90 \%$.

Pada sediaan topikal pengujian $\mathrm{pH}$ dilakukan untuk mengetahui keamanan sediaan krim, $\mathrm{pH}$ yang terlalu basa dapat menyebabkan kulit kering sedangkan $\mathrm{pH}$ yang terlalu asam dapat mengiritasi kulit, maka dari itu sediaan 
krim yang akan dibuat harus sesuai range $\mathrm{pH}$ yang sudah ditentukan (Mailana et al, 2016).Pada gambar 1. Hasil uji pH krim ekstrak etanol buah papaya berada diantara $\mathrm{pH}$ 4,62 - 6,04. Hal ini sesuai dengan yang diharapkan karena rentang $\mathrm{pH}$ sediaan topikal sebaiknya memiliki pH 4,5-6,5 (Engelinaet al, 2013). Semakin tinggi konsentrasi ekstrak pada $\mathrm{krim} \mathrm{A} / \mathrm{M}$ semakin asam $\mathrm{pH}$ yang didapatkan kemungkinan hal ini disebabkan karena ekstrak buah papaya memiliki kandungan berupa senyawa-senyawa flavonoid yang bersifat asam lemah (Juwita \& Djajadisastra, 2011). Pada penelitian Yogiraj (2014) juga menyatakan bahwa adanya vitamin $\mathrm{C}$, amino acid, citric acid, dan molic acid yang bersifat asam pada kandungan buah papaya yang menyebabkan semakin tinggi konsentrasi ekstrak maka nilai pH semakin rendah. Hasil menunjukkan bahwa terjadi perbedaan yang signifkan pada pengujian $\mathrm{pH}$ antara basis, krim ekstrak 1\% (F1), krim ekstrak 3\% (F2) dan krim ekstrak 5\% (F3).

Pengujian viskositas bertujuan untuk mengetahui kekentalan sediaan krim dengan menggunakan alat viscometer. Sediaan krim pada umunya memiliki tipe aliran nonnewtonian. Viskositas krim yang baik berkisar antara 2000-50000 cps dan tipe alir yang ideal untuk sediaan krim yaitu pseudoplastis karena saat dioleskan pada kulit maka viskositas sediaan akan menurun yang berakibat daya sebar akan meningkat sehingga memundahkan saat pemakaian sediaan (Martin et al, 2012). Berdasarkan hasil perhitungan dan gambar grafik hubungan antara $S S$ vs $S R$ dengan nilai KV 1,060 dan FK 3,790 menunjukkan semua sedian krim A/M dengan variasi kosentrasi ekstrak memilki sifat alir pseudoplastis karena nilai koefisien korelasi (r) hubungan antara log $S S$ vs $S R$ lebih besar dibandingkan dengan nilai koefisien korelasi (r) hubungan antara $S S$ vs $S R$ dan nilai slope (b) nya lebih dari 1.Hasil menunjukkan bahwa viskositas krim A/M antara basis F1, F2 dan F3 memenuhi syarat karena berkisar diantara 17793,00-8465,16. Viskositas krim yang baik berkisar antara 200050000 (Martin et al, 2012). Hasil uji viskositas krim A/M ekstrak etanol buah papaya disajikan pada gambar 2.Data yang terjadi pada gambar 3 menunjukkan bahwa terjadi penurunan viskositas setiap penambahan konsentrasi ekstrak etanol daging buah papaya. Untuk mengetahui adanya perbedaan yang bermakna antara formula maupun basis dengan adanya variasi konsentrasi ekstrak maka dilakukan uji SPSS. Hasil menunjukkan bahwa terjadi perbedaan yang signifikan pada pengujian viskositas antara basis, krim ekstrak 1\% (F1), krim estrak 3\% (F2) dan krim ekstrak 5\% (F3). Terjadinya penurunan viskositas pada setiap penambahan konsentrasi ekstrak buah papaya dimungkinkan karena adanya kandungan kadar air dalam ekstrak yang dapat menyebabkan setiap peningkatan ekstrak niali viskositas semakin rendah. Jenis pelarut salah satu faktor yang dapat mempengaruhi kadar air pada ekstrak dimana pada penelitian ini menggunakan pelarut etanol $70 \%$ (Atisantoet al, 2017).

Pengujian daya lekat dilakukan untuk mengetahui berapa lama sediaan krim dapat melekat pada kulit, krim yang baik memiliki daya lekat yang tinggi. Kemampuan krim apabila melekat semakin lama pada kulit, maka zat aktif yang dilepaskan dari basisnya akan semakin banyak diabsorbsi oleh kulit (Ulean et $a l$, 2012). Daya lekat yang lebih baik dapat memungkinkan obat untuk melekat lebih lama dan tidak mudah lepas. Persyaratan daya lekat yang baik untuk sediaan topikal yaitu lebih dari 4 detik (Rachmalia et al, 2016). Hasil uji daya lekat krim ekstrak etanol buah papaya dapat dilihat pada gambar 3. Pada gambar 3 uji daya lekat dapat dilihat urutan krim A/M yang memilki daya lekat paling lama yaitu basis krim dengan waktu lekat 20,2 \pm 0,36 detik kemudian yang kedua yaitu F1 dengan waktu lekat 18,39 \pm 0,14 dan yang ketiga yaituF2 15,12 $\pm 0,08$ dan yang keempat yaitu F3 13,28 \pm 0,13 dengan waktu lekat yang paling kecil. Hasil uji daya lekat menunjukkan bahwa daya lekat antara basis krim F1, F2 dan F3 memenuhi syarat untuk daya lekat pada sediaan topikal karena lebih dari 4 detik (Rachmalia dkk 2016). Pada gambar 6 dapat dilihat bahwa terjadi penurunan daya lekat pada tiap formula seiring penambahan konsentrasi ekstrak etanol buah papaya. Hal tersebut kemungkinan disebabkan oleh adanya penurunan viskositas krim A/M. Hal ini sesuai dengan hasil penelitian Tanjungsari(2012)bahwa nilai viskositas mempengaruhi nilai daya lekat, penurunan viskositas yang menyebabkan waktu daya lekat lebih cepat. Hasil uji statistik pada nilai daya lekat menggunakan Kolmogrov Smirnovmenunjukkan data terdistribusi normal dengan nilai signifikasi $0,942>0,05$ setelah itu diuji dengan menggunakan test of homogeneity of variancesdidapatkan data homogen dengan nilai signifikasi $0,217>0,05$, kemudian dilanjutkan dengan LSD hasil menunjukkan bahwa terjadi perbedaan yang signifikan pada pengujian daya lekat antara basis, krim ekstrak $1 \%(\mathrm{~F} 1)$, krim estrak 3\% (F2) dan krim ekstrak $5 \%(\mathrm{~F} 3)$.

Pengujian daya sebar dilakukan untuk 
melihat kemampuan sediaan dapat menyebar pada permukaan kulit. Semakin tinggi daya sebar yang dihasilkan maka akan mudah diaplikasikan tanpa memerlukan tekanan pada saat dioleskan dikulit (Naibahoet al, 2013). Persyaratan daya sebar untuk sediaan topikal yaitu sekitar 5-7 cm (Ulaen dkk, 2012). Hasil uji daya sebar krim ekstrak etanol buah papaya dapat dilihat pada gambar 4.Pada gambar 4 dapat dilihat antara basis, F1, F2 dan F3 memiliki daya sebar berkisar diantara 5,09-6,12 $\mathrm{cm}$. Hal tersebut sesuai dengan yang diharapkan karena untuk persyaratan daya sebar sediaan topikal yaitu berkisar $5-7 \mathrm{~cm}$ (Ulaen et al.,2012). Pada penelitian ini peningkatan konsentrasi ekstrak menyebabkan peningkatan daya sebar. Hal ini berkaitan dengan viskositas krim A/M yang terjadi penurunan pada peningkatan ekstrak daging buah papaya. Hal ini sesuai dengan penelitian Elcistia et al (2018) daya sebar memiliki kaitan dengan viskositas, apabila viskositas rendah, maka daya sebar krim akan semakin besar karena krim akan semakin mudah mengalir dan menyebar pada permukaan kulit.Hasil uji statistik nilai daya sebar menggunakan Kolmogrov Smirnov menunjukkan data terdistribusi normal dengan nilai signifikasi $0,999>0,05$ setelah itu diuji menggunakan test of homogeneity of variancesdidapatkan data homogen dengan nilai signifikasi 0,200 >0,05, kemudian dilanjutkan dengan uji LSD hasil Pmenunjukkan bahwa terjadi perbedaan yang signifikan daya sebar antara basis, F2 (3\%) dan F3 (5\%) dan antara F1 (1\%), F2(3\%) dan F3(5\%). Sementara itu tidak terdapat perbedaan daya sebar yang signifikan antara basis dan F1 (1\%).

Uji stabilitas fisik bertujuan untuk mengetahui kestabilan fisik dari formula krim ekstrak etanol daging buah papaya yang menggunakan beberapa variasi konsentrasi yaitu $1 \%$, 3\% dan 5\%. Uji ini dilakukan dengan melihat ada tidaknya pemisahan fase setiap formula pada kecepatan $3750 \mathrm{rpm}$ selama 5 jam atau 5000-10000 rpm selama 30 menit, dimana pada kecepatan tersebut sama besarnya dengan pengaruh gaya gravitasi terhadap penyimpanan krim selama setahun (Reiger M, 2000). Hasil pengujian menggunakan sentrifugasi disajikan pada gambar 5. Pada gambar 5 hasil pengujian sentrifugasi $\mathrm{krim} \mathrm{A} / \mathrm{M}$ menggunakan variasi konsentrasi ekstrak dapat dilihat adanya sedikit pemisahan pada F3 sehingga dapat dikatakan formula yang tidak stabil dibandingkan F1 dan F2 karena tidak adanya pemisahan. Kemungkinan nilai viskositas dapat berpengaruh pada stabilitas fisik, dimana F1 dan F2 memilki viskositas yang tinggi dibandingkan
F3. Hal tersebut sesuai dengan penelitian Mailana et al (2016) nilai viskositas berpengaruh terhadap stabilitas fisik. Semakin tinggi viskositas akan semakin stabil karena pergerakan partikel cenderung sulit dengan semakin kentalnya suatu sediaan. Viskositas yang tinggi akan membuat laju sedimentasi sediaan semakin lambat sehingga pembentukan creaming tidak akan terjadi (Pujiastuti et al, 2019). Pada penelitian Noviardi et al (2019) semakin besar kosentrasi ekstrak dalam krim maka viskositas krim akan semakin cair atau semakin tinggi sehingga menyebabkan cepat terjadinya pemisahan fase.

\section{KESIMPULAN}

Variasi konsentrasi ekstrak etanol daging buah papaya memiliki pengaruh terhadap sifat fisik krim $\mathrm{A} / \mathrm{M}$ yaitu dapat menurunkan $\mathrm{pH}$, meningkatkan daya sebar, menurunkan daya lekat, menurunkan viskositas dan berpengaruh pada stabilitas fisik, terjadinya pemisahan pada FIII di karenakan semakin besar konsentrasi ekstrak pada sediaan krim.

\section{DAFTAR PUSTAKA}

Abdiana, R., Dwi, I., A. 2017. Rambut jagung (Zea Mays) sebagai alternatif TabirSurya. Majority.

Aravind, G., Bhowmik, D., Duraivel, S., \& Harish, G. 2013. Traditional and Medicinal Uses of Carica papaya. Journal of Medicinal Plants Studies, 1(1), 7-15.

Arifianti, L., Oktarina, R. D., \& Kusumawati, I. 2014. Pengaruh Jenis Pelarut Pengektraksi. E-Journal Planta Husada, 2(1), 3-6.

Atisanto, V.S., Mulyani, S., \& Triani, I. G. A.2017. Karakteristik Ekstrak pada Buah Kelubi (Eliodoxa Conferta). Rekayasa Dan Manjemen Argo Industri.

Broto, L., Kardono, S., \& Artanti, N. 2013. Development of Papaya Latex, Papaya Extract (Carica papaya L.) and Yam Bean Tuber Extract (Pachyrrhizus erosus (L.) Urb.) for Skin Lightening Lotion Based on Tyrosinase Inhibition and Antioxidant Activities. Jurnal Ilmu Kefarmasian Indonesia, 11(2), 191196.

Chang. 2009. An Update Review of Tyrosinase Inhibitors. Journal of Moleculer Sciences, 10(6), 2440-2475.

Chang, T., Ding, H., \& Lin, H. 2005. Identifyng $6,7,4^{\prime}$ - Tridydroxyflavone as a Potent 
Tyrosinase Inhibitor. Biosence, Biotechnology, Biochemistry, 69(10)(1999-2001).

Costin, G. E., \& Hearing, V. J. 2007. Human skin pigmentation: Melanocytes modulate skin color in response to stress. FASEB Journal, 21(4), 976-994. https://doi.org/10.1096/fj.06-6649rev

D’Orazio, J., Jarrett, S., Amaro-Ortiz, A., \& Scott, T. 2013. UV radiation and the skin. International Journal of Molecular Sciences, 14(6), 1222212248.

Dalimartha, S. 2003. Atlas Tumbuhan Obat Indonesia (Jilid 3). Jakarta: Puspa Swara.

Dewi, Rahmawati. Anita, Sukmawati. dan Peni, I. 2010. Formulasi krim minyak atsiri rimpang temu giring ( curcuma heyneana val \&zijp ): uji sifat fisik dan daya antijamur formulation cream containing essential oil of curcuma heyneana: physical characteristics test and in vitro antifungal activity.Majalah Obat Tradisional, 15(2), 56-63.

Dewi, M. 2018. Total Fenolik dan Flavonoid serta Potensinya Sebagai Antiaging dan Penghambat Tirosinase Ekstrak Aseton Buah Pepaya dengan Variasi Konsentrasi Pelarut. Universitas Ahmad Dahlan.

Dewi, Rosmala., Effionora, Anwar., Yunita. KS. 2014. Uji Stabilitas Fisik Formula Krim yang Mengandung Ekstrak Kacang Kedelai (Glycine max). Pharm Sci Res. ISSN 2407-2354.

Djuanda, A. 2000. Ilmu Penyakit Kulit dan Kelamin.

Donglikar, M., \& Deore, S. 2016. Sunscreen : A Review. Pharmacogn J, 171-179.

Donglikar, M. M., \& Deore, S. L. 2017. Development and evaluation of herbal sunscreen. Pharmacognosy Journal, 9(1), 83-97.

Dutra, R.P., Abreu, A.B.V.D., Cunha, M.S., Batista, M. C. A. 2014. Phenolic acids, Hydrolysable tannins and antioxidant activity of geogropolis from the stingless bee Melipona Fasciculita Smith. Journal of Agricultural and Food Chemistry.

Edityaningrum, C. A., Kintoko, K., Zulien, F., \& Widiyastuti, L. 2018. Optimization of Water Fraction Gel Formula of Binahong Leaf (Anredera cordifolia (Ten.) Steen) With Gelling Agent of Sodium Alginate and Carboxymethyl Chitosan Combination. Majalah Obat
Tradisional, 23(3), 97.

Emmy, S., Daili, Sjamsoe., Menaldi, L., Wisnu, M. 2005. Penyakit/ Kulit yang Umum di Indonesia di Sebuah Panduan Bergambar.

Engelina, N., Fahrurroji, A., dan Pratiwi, L. 2013. Optimasi Krim sarang burung walet putih (aerodramus fuciphagus) tipe M/A dengan variasi emulgator sebagai pencerah kulit menggunakan Simplex Latice Design.

Ferreira, V. S., Júnior, J. B. G., Oliveira, C. M. S. C., Takeuchi, R. M., Santos, A. L., \& Trindade, M. A. G. 2013. Voltammetric analysis of sun-block preparations containing octocrylene and its association with 2-Hydroxy-4methoxybenzophenone and octyl methoxycinnamate. Microchemical Journal, 106, 378-383.

Grag, A., Anggrawal, D., Grag, S., \& Sigla, A. 2002. Spreading of Semisolid Formulation. Pharmaceutical Technologi, 84-102.

Handali, S., Hosseini, H., Ameri, Abdulgami., Monghimpir, E. 2011. Formulation and evaluation of an antibacterial cream from Oxalis corniculata aqueous extract. Medical Plant Research Center.

Haque, A., \& Sugihartini, N. 2005. Evaluasi Iritasi dan Uji Sifat Fisik pada Sediaan Krim M/A Minyak Atsiri Bunga Cengkeh dengan Berbagai Variasi Konsentrasi. Jurnal Farmasi Indonesia, 12(2), 131-139.

Harahap, M. 2000. Ilmu Penyakit Kulit. Edisi 1. Jakarta. Hipokrates. Hal S-5

Istiqomah. 2013. Perbandingan Metode Ekstraksi Maserasi dan Sokletasi Terhadap Kadar Piperin Buah Cabe Jawa (Piperis retrofracti fructus). Universitas Islam Negeri Syarif Hidayatullah.

James, LC., Barger, TG., dan., Elston, D. . 2006. Andrews diseases of the skin: Clinical dermatology (10th ed).

Juwita, N. K., \& Djajadisastra, J. 2011. Uji Penghambatan Tirosinase Dan Yang Mengandungekstrak Kulit Batang Nangka ( Artocarpus heterophyllus ). 8(3), 127-140.

Kalangi, S. J. R. 2014. Histofisiologi Kulit. Jurnal Biomedik (Jbm), 5(3), 12-20.

Karina, R. 2014. Formulasi dan Uji Sifat Fisikokimia Sediaan Losio dengan Variasi Konsentrasi Vitamin E.Skripsi. Universitas TanjungPura. Pontianak. 
Khan, M. 2018. Sun Protection Factor Determination Study of Some Sunscreen Formulation Used in Cosmetic for Their Selection. European Journal of Dermatology. 8(5): 148-151.

Khomaria, Y. 2018. Kandungan Total Fenolik dan Flavonoid serta Potensinya Sebagai Antiaging dan Penghambat Tirosinase Ekstrak Etanol Buah Pepaya dengan Variasi Konsentrasi Pelarut.TESIS. Universitas Ahmad Dahlan.

Kolarsick, p., Maria, A., Kolarsick, MSN., and Carolyn, G. 2011. Anatomy and Physiology of the skin. SKIN CANCER.

Kumalasari, E., \& Sulistyani, N. 2011. Aktivitas Antifungi Ekstrak Etanol Steen .) Terhadap Candida Albicans Serta Skrining Fitokimia Antifungal Activity Of Ethanol Extract Of Binahong Stem ( Anredera Cordifolia ( Tenore ) Steen ) Against Candida Albicans And The Phytochemical Screening. Jurnal Ilmiah Kefarmasian, 1(2), 51-62.

Lavi, N. 2012. Sunscreen For Travellers. Universitas Of Udayana.

Mailana, D., \& Harwoko. 2016. Formulasi Sediaan Krim Antioksidan Ekstrak Etanolik Daun Alpukat (Persea americana mill). Acta Pharmaciae Indonesia, 4(2), 13-20.

Maisarah, A., Nurul, A., Asmah, R., \& Fauziah, O. 2013. Antioxidant Analysis of Diffrent Parts of Carica papaya. International Food Research Journal, 20(3), 1043-1048.

Martin, A., Awabrick, J., \& Cmmarat, A. 2012. Farmasi Fisik Dasar-Dasar Farmasi Fisik dalam Ilmu Farmasetik. Jakarta: Universitas Indonesia.

Masum, M., Yamaguchi, K., \& Mitsunaga, T. 2019. Tyrosinase Inhibitors from Natural and Syntetic Sources as SkinLightening Agents. Reviews in Agricultural Sciences, 7, 41-58.

Mescher, A. 2010. Junquiea's Basic Histology Text \& Atlas (12 th ed). Newyork: The McGraw-Hill Companies, Inc.

Mukhlishah, N. R. izzatul, Sugihartini, N., \& Yuwono, T. 2016. Daya Iritasi dan sifat fisik sediaan salep minyak atsiri bunga cengkeh (syzigium aromaticum) pada basis hidrokarbon. Majalah Farmaseutik, 12(1), 372-376.

Naibaho, O. H., Yamlean, P. V. Y., \& Wiyono, W.2013. Pengaruh Basis Salep
Terhadap Formulasi Sediaan Salep Ekstrak Daun Kemangi (Ocimum sanctum L.) Pada Kulit Punggung Kelinci yang Dibuat Infeksi Staphylococcus aureus. Jurnal Ilmiah Farmasi-UNSRAT, 2(2), 27-34.

Noviardi, Harry., Ratnasari, Devi., Fermadianto, Muhammad. 2019. Formulasi Sediaan Krim Tabir Surya dari Ekstrak Etanol Buah Bisbul (Diospyrus blancai). Jurnal Ilmu Kefarmasian Indonesia. Vol. 17 No 2.

Nurul, Fahmi, Ali., Hendra, Stevani., Dwi Rachmawati. 2019. Formulasi dan stabilitas sediaan body scrub Bedda Lontong dengan variasi konsentrasi Trietanolamin. Media Farmasi. Poltekkes Kemenkes Makassar.

Ohguchi, K., Tanaka, T., \& Kido, T. 2003. Effect of Hydroxystilbene Derivatives on Tyrosinase Activity. Biochemistry Biophysical Research Community, 307(4), 861-863.

Panche, A. N., Diwan, A. D., \& Chandra, S. R. 2016. Flavonoids: An overview. Journal of Nutritional Science, 5.

Pratama dan Zulkarnain. 2015. Uji Spf In Vitro dan Sifat Fisik Beberapa Produk Tabir Surya Yang Beredar Di Pasaran. Majalah Farmaseutik, 11(1), 275-283.

Pujiastuti, Anastasia, Kristiani, Monica. 2019. Formulasi dan Uji Stabilitas Mekanik Hand and body Lotion Sari Buah Tomat (Licopercison esculentum Mill.) sebagai Antioksidan. Jurnal Farmasi Indonesia. 16 (1), 42-55.

Putri, C. 2018. Total Fenolik dan Flavonoid serta Potensinya Sebagai Antiaging dan Penghambat Tirosinase Ekstrak Metanol Buah Pepaya dengan Variasi Konsentrasi Pelarut.Thesis. Universitas Ahmad Dahlan.

Rai, R., Shangga, S., and S. 2012. Update on Photoproctection. Journal of Dermatologi, 335-342.

Rokhmawati, A., Gunadi, A., \& Indrayudha, P. 2014. Daya Antibakteri Ektrak Buah Takoak (Solanum Tarvum Swartzi) terhadap pertumbuhan Streptococcus mutans. Art Ilmiah HPM, 1, 1-7.

Saewan, N., \& Jimtaisong, A. 2013. Photoprotection of natural flavonoids. Journal of Applied Pharmaceutical Science, 3(9), 129-141.

Sayuti, Nutrisia, Aquariusinta. 2015. Formulasi dan Uji Stabilitas Fisik Sediaan Gel Ekstrak Daun Ketepeng Cina (Cassia allata L.,). Jurnal Kefarmasian 
Indonesia. Vol. 5 No 2.

Setiaji, A., Perairan, D. B., Perikanan, F., \& Ilmu, D. A. N. 2009. Untuk Pencegahan Dan Pengobatan Ikan Lele Dumbo Clarias Sp Yang Diinfeksi Bakteri Aeromonas hydrophila.

Shenekar, P. N., Ukirade, P. S., Salunkhe, S. D., Sutar, S. T., Magdum, C. S., Mohite, S. K.Metri, S. M. 2014. In vitro evaluation of sun protection factor of fruit extract of Carica papaya L. as a lotion formulation. European Journal of Experimental Biology, 4(2), 44-47.

Slominski, A., Tobin, D. J., Shibahara, S., \& Wortsman, J. 2004. Melanin Pigment.Pdf. 1155-1228.

Suprapti, L. 2005. Dasar- Dasar Tekhnologi Pangan. Surabaya: Vidi Ariesta.

Suryati, Henry, L., \& Dachriyanus. 2015. Formulaation of Sunscreen Cream of Germanicol cinnamate from the Leaves of Tabat Barito (Ficus deltiodes Jack) and assay of it's Sun Protection Factor. International Journal of Pharmaceutical Sciences Review and Research, 104-107.

Tabrizi, H., Mortazan, S., Kamalinejed., M. 2003. An in vitro evalution of various rosa damascena flower extract as a natural antisolar agent. International Journal of Cosmetic Science, 25, 259265.
Tanjungsari, D. 2012. Formula sediaan gel ekstrak etanolik buah mahkota dewa (Phaleria macropora (Scheff) Boerl) dengan basis carbomer.Skripsi.

Tranggono, R., \& Latifah, F. 2007. Buku Pegangan Ilmu Pengetahuan Kosmetik. Jakarta: Gramedia Pustaka Utama.

Ulean, S., Banne, Y., \& Suatan, R. 2012. Pembuatan Salep Anti Jerawat dari Ekstrak Rimpang Temulawak (Curcuma xanthorriza Roxb). Jurnal Ilmiah Farmasi, 3(2), 45-49.

Yanhendri., Yenny, S. W. 2012. Berbagai Bentuk sediaan Topikal dalam Dermatologi. Jakarta : Hippocrates.

Yamaguchi, Y., Brenner, M., \& Hearing, V. J. 2007. The regulation of skin pigmentation. Journal of Biological Chemistry, 282(38), 27557-27561.

Yumas, M. 2016. Formulasi Sediaan Krim Wajah Berbahan Aktif Ekstra Metanol Biji Kakao Non Fermentasi (Theobroma Cacao L) Kombinasi Madu Lebah.Jurnal Industri Hasil Perkebunan, 11(2), 75-87.

Zolghadri, S., Bahrami, A., Hassan Khan, M. T., Munoz-Munoz, J., Garcia-Molina, F., Garcia-Canovas, F., \& Saboury, A. A. 2019. A comprehensive review on tyrosinase inhibitors. Journal of Enzyme Inhibition and Medicinal Chemistry, 34(1), 279-309. 